\title{
Postharvest management of Heliconia psittacorum $\times$ H. spathocircinata cv. Tropics
}

\author{
Carrera-Alvarado, Gisela ${ }^{1}$; Arévalo-Galarza Ma. de Lourdes ${ }^{2 *}$; Velasco-Velasco, Joel ${ }^{1}$; \\ Ruiz-Posadas, Lucero del Mar ${ }^{2}$; Salinas-Ruíz, Josafhat ${ }^{1}$; Baltazar-Bernal, Obdulia ${ }^{1}$
}

${ }^{1}$ Colegio de Postgraduados, Campus Córdoba Km. 348 Carretera Federal Córdoba-Veracruz, Municipio de Amatlán de los Reyes, Ver. C.P. 94946 México. ${ }^{2}$ Colegio de Postgraduados, km 36.5 Carretera México-Texcoco, Montecillo, Texcoco, C.P. 56230, México

*Corresponding Author: larevalo@acolpos.mx

\begin{abstract}
Objetive: Evaluate different techniques to prolong the postharvest life of Heliconia psittacorum x H. spathocircinata cv. Tropics.

Design/methodology/approach: Two experiments were carried out; in the first it was evaluated the effect of five pulse solutions $\left[\left(\mathrm{T} 1=\right.\right.$ control (water); T2 $=$ Hydraflor $^{\circledR} 100\left(0.5 \mathrm{~g} \mathrm{~L}^{-1}\right) ; \mathrm{T} 3=$ Hydraflor $^{\circledR} 100\left(0.5 \mathrm{~g} \mathrm{~L}^{-1}\right)+$ sucrose $(5 \% \mathrm{~W} / \mathrm{v}) ; \mathrm{T} 4$ = salicylic acid $(1 \mathrm{mM})$ and $\mathrm{T} 5$ = salicylic acid $(1 \mathrm{mM})+$ sucrose $(5 \% \mathrm{w} / \mathrm{v})$ ] prior to storage at $11^{\circ} \mathrm{C}$ and $85 \% \mathrm{RH}$ for $10 \mathrm{~d}$. In the second experiment, a wax coating was applied to the heliconia bracts and then maintain at $13{ }^{\circ} \mathrm{C}$ and $84 \% \mathrm{RH}$ for $10 \mathrm{~d}$; after storage the stems were placed in water or salicylic acid solution $(1 \mathrm{mM})$. The results were analyzed by a completely randomized design, 10 replicates were used per treatment, one stem was one experimental unit. An ANOVA and a means comparison test (Tukey, $\alpha=0.05$ ) were performed with the SAS version 9.4

Results: The anatomy of heliconia stems determines their vase life, since they have wide xylem vessels susceptible to cavitation, for which the absorption of water is limited, also and non-functional stomata in the bracts, which increase the loss of moisture from the tissue. The use of pulse solutions or preservatives has little effect in prolonging the life of heliconia stems. Therefore, the application of wax creates a physical barrier that maintains the turgor of the stems, reduces oxidation, maintaining the bracts quality and increased the total postharvest life for $6 \mathrm{~d}$ more than the control stems.
\end{abstract}

Study limitations/implications: No limitations were found in this study

Findings/conclusions: The postharvest life of heliconia is conditioned by the loss of turgor and low water absorption, which leads to an early wilting of the inflorescences. The application of pulse solutions or preservatives have little effect in prolonging the life of the vase, so the most suitable technique to preserve the quality of the stems is waxing.

Palabras clave: cold storage, water absortion, waxing, pulse solution, preservative solution, vase life.

\section{INTRODUCTION}

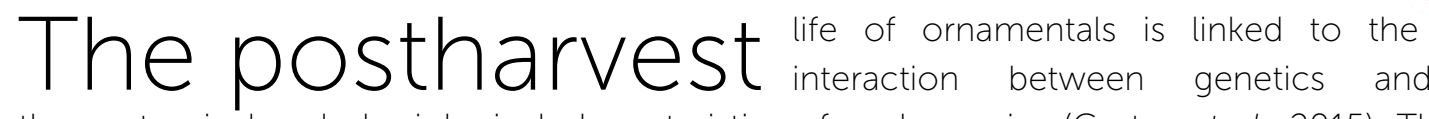
the anatomical and physiological characteristics of each species (Castro et al., 2015). The shelf life of cut flowers depends on the absorption of water, respiration, and transpiration; and biochemical changes such as enzymatic activity, lipid peroxidation, permeability of the 
cell membrane, associated with oxidative stress (Abri et al., 2013). Then the turgor and fresh weight of the cut stems, depend on their ability to absorb water, which is determined by the water conductivity and characteristics of the vascular bundles of the stems (van Meeteren and van Gelder, 1999). Likewise, transpiration is essential to regulate water absorption, however if the stomata do not respond adequately to environmental factors, a negative water balance develops, which implies greater loss of water than that absorbed by the stem, which leads to accelerated wilting (van Doorn, 2012).

The use of pulse or preservative solutions help to maintain physiological processes, due to their low $\mathrm{pH}$, and content of sucrose and biocides that reduce the microbial load of the water, improving the water absorption and supplying the necessary substrate for respiration (Pun and Ichimura, 2003). In tropical species such as Zingiber spectabile, the use of Hydraflor ${ }^{\circledR} 100$ (Floralife Co.) (16 mL L ${ }^{-1}$ ) increased the vase life (Coelho et al., 2012). The use of salicylic acid (AS) solution in cut flowers of anthurium (Anthurium andraeanum cv. Sirion) delayed the spathe browning, associated with a low polyphenol oxidase activity and the delay of electrolyte leakage (Aghdam et al., 2016). On the other hand, wax coatings on tropical flowers have been proven to increase longevity by lowering the transpiration and respiration and in addition improving their appearance.

Like other fruit and vegetable products, cut flowers are highly perishable, for that reason must be handled and stored properly. To maintain its value, quality, and prolong the vase life, postharvest techniques are needed (Folha et al., 2016). However, in Heliconia psittacorum $\times H$. spathocircinata $\mathrm{cv}$. Tropics little information is available for its postharvest handling, so the aim of this work was to determine an adequate treatment to prolong its shelf life.

\section{MATERIALES Y MÉTODOS Plant material}

Inflorescences of $\mathrm{H}$. psittacorum $\times \mathrm{H}$. spathocircinata $\mathrm{cv}$. Tropics were obtained from a commercial plantation located in Ixtaczoquitlan, Veracruz (18 $8^{\circ} 52^{\prime} 18.90^{\prime \prime} \mathrm{N}$ and $97^{\circ} 01^{\prime} 34.84^{\prime \prime} \mathrm{W}$, altitude $998 \mathrm{~m}$ ). The stems were transferred to the laboratory at room temperature (18$21^{\circ} \mathrm{C}$ ). Inflorescences with two to three open bracts were selected, cleaned (removing the flowers from inside the bracts), washed and standardized stem length of $100 \pm 1 \mathrm{~cm}$.

\section{Anatomical description}

Histological preparations of the stem and bracts were made and observed under a scanning electron microscope in order to describe the stomatal (type and stomatal frequency), and stem vascular system characteristics. Transpiration test was performed with a gravimetric method, based on the weight loss of 10 stems in a controlled environment $\left(24^{\circ} \mathrm{C}, 60 \% \mathrm{RH}\right.$ and $12 \mathrm{~h}$ photoperiod).

\section{Experiment 1}

One hundred stems were harvested and divided into five batches, then placed in a pulse solution (12 h) prior to storage: $\mathrm{T} 1=$ control (water); $\mathrm{T} 2=$ Hydraflor $^{\circledR} 100$ $\left(0.5 \mathrm{~g} \mathrm{~L}^{-1}\right) ; \mathrm{T3}=$ Hydraflor ${ }^{\circledR} 100\left(0.5 \mathrm{~g} \mathrm{~L}^{-1}\right)+$ sucrose $(5 \% \mathrm{~W} / \mathrm{v}) ; \mathrm{T} 4=$ salicylic acid $(1 \mathrm{mM})$ and $\mathrm{T} 5=$ salicylic acid $(1 \mathrm{mM})+$ sucrose $(5 \% \mathrm{w} / \mathrm{v})$. Later they were stored at $11^{\circ} \mathrm{C}$ and $85 \% \mathrm{RH}$ for $10 \mathrm{~d}$. Half of the stems per treatment were stored in water (wet condition) and the other half in dry (in plastic bags). After storage the variables the stems were place in water and variables: fresh weight (FW), water consumption (WC), percentage of cell membrane integrity (CMI) and vase life (VL) were evaluated.

\section{Experiment 2}

Sixty stems were selected and divided into two groups: 1) control (30 stems) and 2) waxed (30 stems). The bracts were waxed (Lustr $227 \mathrm{~F}^{\circledR}$, Decco) based on carnaubashellac, dried for $3 \mathrm{~h}$. They were handled under two conditions: room temperature $\left(22{ }^{\circ} \mathrm{C}, 68 \% \mathrm{RH}\right)$ and cold storge $\left(13{ }^{\circ} \mathrm{C}\right.$ and $\left.84 \% \mathrm{RH}\right)$ for $10 \mathrm{~d}$ in a dry condition; after storage, the stems were placed in water or salicylic acid solution $(1 \mathrm{mM})$. Then treatments were: Control = stems in water at room temperature; $W W=$ stems waxed placed in water at room temperature; RW $=$ stems cold stored and placed in water; RSA = stems cold stored and placed in salicylic acid (1 mM); RWW = stems waxed and cold stored and placed in water; RWSA = waxed stems and cold stored and placed in salicylic acid solution (1 $\mathrm{mM}$ ). Each treatment had 10 repetitions, each stem in one replicate. During the VF, the solution was renewed every $5 \mathrm{~d}$ and a cutout of the base of the stem of $2-3 \mathrm{~cm}$.

\section{Variables evaluated}

Fresh weight (FW \%) and water or solution consumption (WC or SC): The fresh weight of the heliconia stem was recorded with a digital scale. The results were expressed as a percentage of fresh weight loss related to the original weight. Solution consumption was evaluated as the difference between the initial and final volume consumed 
by each flower stem. The results were expressed as $\mathrm{mL}$ of solution per gram of fresh weight $\left(\mathrm{mL} \mathrm{g}^{-1}\right)$.

Cell Membrane Integrity (CMI \%): Samples of three discs (10 $\mathrm{mm}$ in diameter) were taken from the bract tissue of the second bract. The method of Mangave et al., (2013) was followed.

Vase life (VF) and total vase life (TVL): Vase life was evaluated as the number of days elapsed since they left storage until the flower stems showed visible signs of deterioration. To evaluate the visual quality of the inflorescences, an A - D scale was designed (Figure 1), where grade $D$ was considered the end of the vase life of the stems. The total postharvest life was determined as the sum of the days of storage plus the days of vase life.

\section{Statistical analysis}

In both experiments the variables results were analyzed by a completely randomized design, 10 replicates were used per treatment, one stem was one experimental unit. Analysis of variance (ANOVA) was performed for all data and

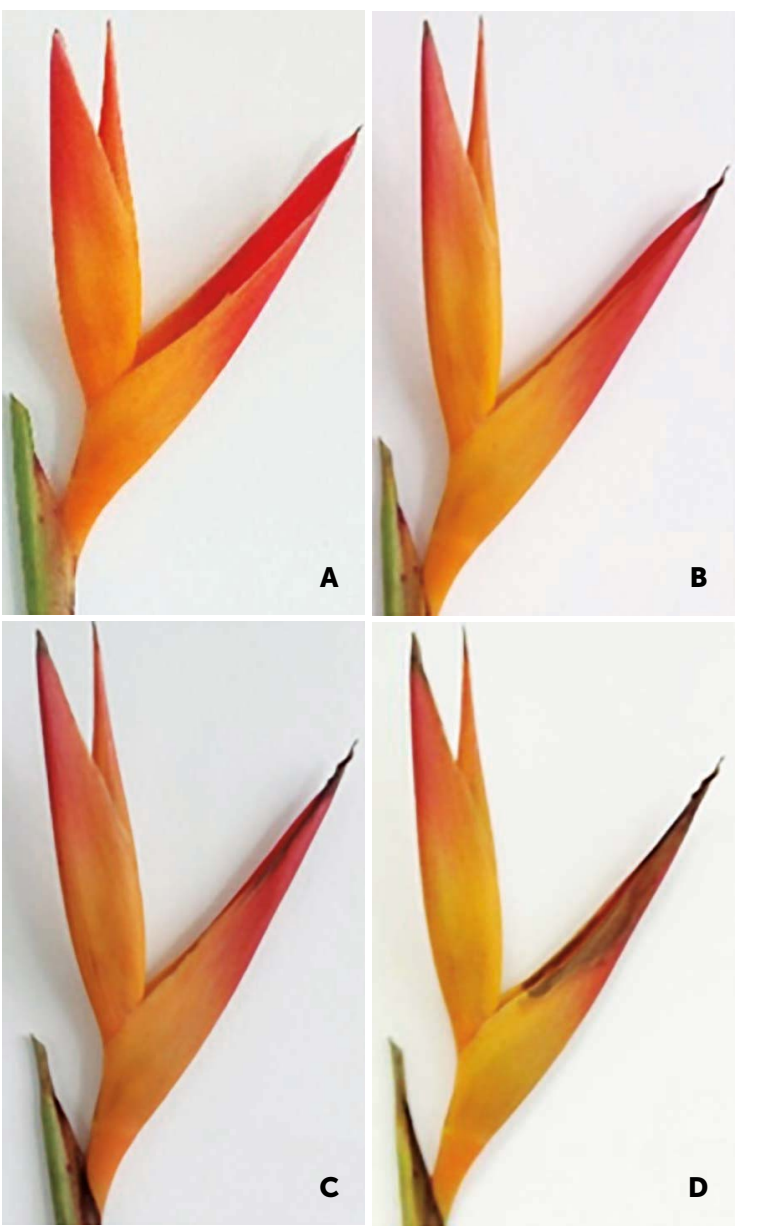

Figure 1. Wilt scale in inflorescences of Heliconia psittacorum $\times H$. spathocircinata cV. Tropics.
We found low response of these stomata to environmental factors, which suggests non-functional type, which do not respond to temperature, light, or $\mathrm{RH}$, that induce dehydration or water stress, leading to the development of a negative water balance and consequently the end of the vase life (van Doorn, 2012). Elibox and Umaharan (2008) report that the stomata of non-foliar organs such as stem, bracts and petals are not always functional.

The bracts contain air channels, fiber bundles distributed very closely to each other on the periphery of the abaxial region (Figure $2 \mathrm{C}$ ), and vascular bundles of a length of about $234.60 \mu \mathrm{m}$, aligned between the fiber bundles and the air channels. (Figure 2D). In the pseustem in the outer the values were analyzed with the mean comparison test (LSD, 0.05). All statistical analyzes were performed with SAS $^{\circledR}$ version 9.4 .

\section{RESULTS AND DISCUSION Anatomical description}

$H$. psittacorum $\times H$. spathocircinata $\mathrm{cv}$. Tropics is an ornamental plant native to South America. It has a musoid growth habit, that is, with upright leaves and very long petioles. Its height can reach $2 \mathrm{~m}$ with leaves blade of 37 to $60 \mathrm{~cm}$ long, the inflorescence is terminal and erect, bracts type cimbiform, distic, and range in number from 3 to 7 per inflorescence (Whistler, 2000; Arriechi \& Sanabria, 1995). The bracts have paracytic stomata, characterized by presenting two attached cells at the same level as the epidermal ones, arranged parallel layer, fiber bundles were observed in great quantity in the periphery, a spongy aerenchyma covering a large part of the surface (Figure 2E); while the central part is made up mainly of vascular bundles with an average channels for the vapor exchange between the plant and atmosphere (transpiration), and their functionality contributes or not to the water loss in the flowers (Huang et al., 2018). An opposite behavior occurs in cut flowers such as Rosa hybrida cv. Akito with a good correlation between stomatal functionality and fresh flower weight and vase life (Woltering and Paillart, 2018).

\section{Experiment 1}

The stem water balance involves the absorption, transport, transpiration, and the capacity of the tissues length of $418.02 \mu \mathrm{m}$ (Figure 2F). Stomata are the main 

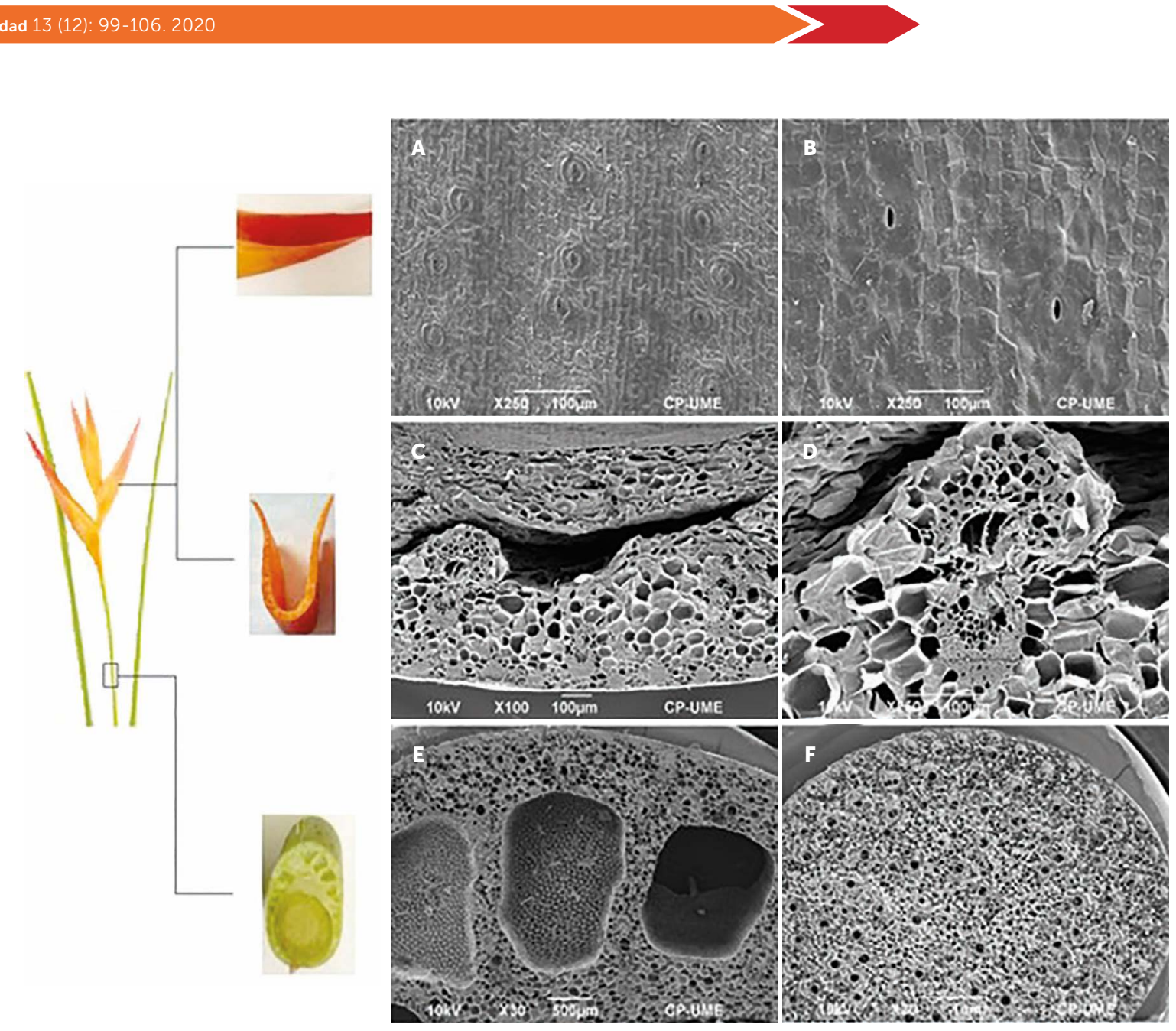

Figure 2. Micrograph of the stem of $H$. psittacorum $\times H$. spathocircinata $c v$. Tropics. A) abaxial and B) adaxial of the epidermis of the bracts; C) Fiber bundles, air channels; D) vascular bundle of a cross section of the bract; E) cross section of the pseudostem: fiber bundles, vascular bundles and aerenchyma and F) vascular bundles of the central part.

in water to retain, all these factors contributed to keep the turgor of cut flowers and consequently the vase life (Moraes-Dias, 2016; Bañuelos-Hernández et al., 2016).

In general, the fresh weight two days after cold storage was significantly higher $(P \leq 0.0001)$ in the stems that were kept in water than those maintained in dry. The stems that preserved the FW were those treated with pulse solution T3 (Hydraflor ${ }^{\circledR} 100+$ sucrose) with $98 \%$ of the FW after storage (Figure 3A). The stems with the greatest weight loss were those in which sucrose was applied and kept dry, however, they were the stems that had the highest water consumption (Figure 3B). Similar results have been reported in species such as Eustoma grandiflorum "ABC Purple" (Ahmad et al., 2012), Rosa sp. and Gerbera jamesonii (Berlingieri-Durigan and Mattiuz, 2009; Mosqueda-Lazcares et al., 2012) where flowers stored dry had a higher water consumption during their vase life than those stored wet. The WC of all treatments was around 0.08 to $0.11 \mathrm{~mL} \mathrm{~g}^{-1}$ (two days after VF), being the stems of T1 (control) and T4 (salicylic acid) and those that presented the highest WC (Fig. 3 B).

It is interesting to note that the CMI was significantly lower $(P \leq 0.0001)$ in the stems stored humid than in those kept dry. The control (dry) treatment was the one that maintained a very similar percentage $(81.20 \%)$ to the initial value, followed by T2 (Hydraflor $\left.{ }^{\circledR} 100\right)$ and T4 (salicylic acid) (78\%), of dry storage; while T3 (Hydraflor ${ }^{\circledR} 100+$ sucrose) was the treatment that presented the greatest damage to the membrane in both wet $(68.03 \%)$ and dry storage (74.59\%) (Figure 3C). Membrane dysfunction is one of the adverse impacts of cold stress on tropical crops. At low temperatures, the transition of crystalline liquid to a rigid gel provoked to a decrease in the selective permeability of the membrane leads oxidation, which decreases the commercial value of flowers (Aghdam et al., 2016).

The VF of heliconia at room temperature was $7 \mathrm{~d}$, their senescence was characterized by wilting at the apex of 

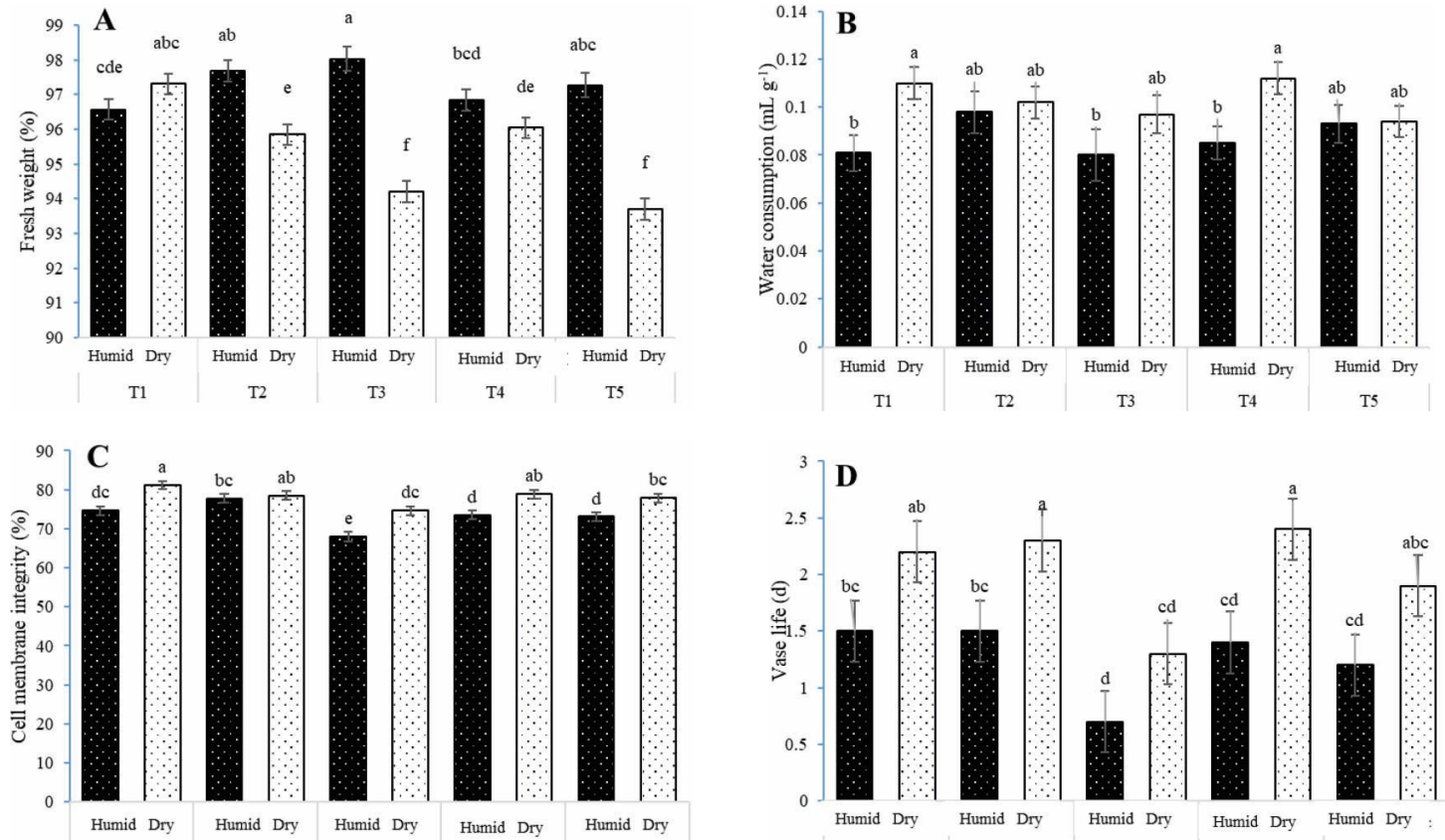

Figure 3. Postharvest variables of Heliconia psittacorum $\times$ H. spathocircinata cv. Tropics two days after cold storage (10 d, at $11{ }^{\circ} \mathrm{C}$ and $\left.85 \% \mathrm{RH}\right)$ with a previous pretreatment with pulse solutions. A) Fresh weight (\%), B) Water consumption ( $\mathrm{mL} \mathrm{g}^{-1}$ ), and C) Cell membrane integrity (\%) and D) Vase life. Each bar represents the mean of ten observations + standard error. T1 = control (water); T2 = Hydraflor ${ }^{\circledR} 100\left(0.5 \mathrm{~g} \mathrm{~L}^{-1}\right) ; \mathrm{T} 3=$ Hydraflor $^{\circledR} 100(0.5 \mathrm{~g} \mathrm{~L}-1)$ + sucrose $(5 \% \mathrm{w}$ v); T4 = salicylic acid $(1 \mathrm{mM})$ and $\mathrm{T} 5=$ salicylic acid $(1 \mathrm{mM})+$ sucrose $(5 \% \mathrm{w} / \mathrm{v})$. Values with equal letters are not statistically different $(P \leq 0.05)$

the bracts and a necrotic tissue. The stems that were stored in humid cold storage, the VF was not greater than $1.5 \mathrm{~d}$, also $60 \%$ of the stems of T3 $\left(\right.$ Hydraflor $^{\circledR} 100$ + sucrose) at the end of storage showed browning in the bracts. All the stems that were stored dry, had about two days of VF (Figure 2D). In heliconia, it has been reported that bract wilt and stem thinning are the typical symptoms of senescence (Leyva-Ovalle et al., 2011). In anthurium (Anthurium andreanum), a delayingd browning of the spathe was associated with high values of CMI in treatments with salicylic acid (Aghdam et al., 2016). We can highlight that the low water absorption of heliconia stem is related to their wide xylem vessels of the stem, so the application of pulse solutions does not contribute significantly improve its vase life.

\section{Experiment 2}

The WL was significantly lower for the stems that were maintained under room temperature (control and WW); while the stems in cold storage had higher values particularly those without wax (RW, RSA), with around 30 to $50 \%$ more WL (Table 1). This can be attributed to the influence of wax on gas exchange without the effect of SA that in previous reports showed the increased of vase life by promoting stomatal closure (Villanueva-Couoh et al., 2009).
The SC had an inverse behavior to $\mathrm{WL}$, and it was significantly higher $(p \leq 0.006)$ in the stems of the control and WW treatments and it was reduced by 50 - $60 \%$ on the cold stored stems (RW, RSA, RWW and RWSA). Regarding the preservative solution of salicylic acid (1 mM) and water, no clear effect was observed (Table 1). Leyva-Ovalle et al., (2011) mention that in stems of heliconia and roses, both species maintain better turgor when they are kept in water than in hydrogel. Additionally, heliconia stems conduct water and nutrients at a much lower speed than roses, due to the fact that they are thicker stems and mostly made of spongy tissue.

The end of the vase life of the cold stored stems was characterized by dark spots with a burnt appearance of the bracts (Figure 4). After cold storage, the vase life compared to the control stems at room temperature was reduced by approximately $5.5 \mathrm{~d}$ in the stems without wax (RW and RAS) and by around $4.3 \mathrm{~d}$ for the wax stems (RWW and RWSA). Regarding to the TVL, the treatments with the best results were those waxed, with around $15 \mathrm{~d}$ of postharvest life, with no significant difference ( $P \leq 0.0001)$ between the use of water or SA as preservative solution (Table 1). Since the loss of turgor is a consequence of water stress, in heliconia it is essential 
to avoid the loss of water from the tissues, which was achieved with the application of wax (van Doorn, 2012).

Bañuelos-Hernández et al. (2016) evaluated different conditions of storage of Heliconia cv. Tropics from 12 to $26{ }^{\circ} \mathrm{C}$ and $\mathrm{RH}$ between 37 and $90 \%$, been the best temperature at $15{ }^{\circ} \mathrm{C}$ with $63 \% \mathrm{RH}$, with $\mathrm{VL}$ of 6.6 $\mathrm{d}$ and a TVL of $16.6 \mathrm{~d}$. In the present study, the VL of waxed stems at room temperature was $13.81 \mathrm{~d}$ and at $13{ }^{\circ} \mathrm{C}$ and $84 \% \mathrm{RH}$ and a VPT of $15.87 \mathrm{~d}$
Table 1. Postharvest variables evaluated two days after storage in stems of Heliconia psittacorum $\times \mathrm{H}$. spathocircinata cv. Tropics kept at room temperature $\left(22 \pm 2{ }^{\circ} \mathrm{C}\right.$ and $69 \%$ $\mathrm{RH})$ and cold storage $\left(13^{\circ} \mathrm{C}\right.$ and $\left.84 \% \mathrm{RH} ; 10 \mathrm{~d}\right)$.

\begin{tabular}{l|c|c|c|c}
\multicolumn{1}{c|}{ Treatment } & $\% \mathrm{WL}$ & $\mathrm{SC}\left(\mathrm{mL} \mathrm{g}^{-1}\right)$ & $\mathrm{VL}(\mathrm{d})$ & $\mathrm{TVL}(\mathrm{d})$ \\
\hline Control & $2.90 \mathrm{c}$ & $0.150 \mathrm{a}$ & 9.93 & $9.93 \mathrm{c}$ \\
\hline $\mathrm{WW}_{\mathrm{W}}$ & $2.86 \mathrm{c}$ & $0.119 \mathrm{~b}$ & 13.81 & $13.81 \mathrm{~b}$ \\
\hline $\mathrm{RW}_{W}$ & $3.73 \mathrm{ab}$ & $0.077 \mathrm{~cd}$ & 4.40 & $14.40 \mathrm{~b}$ \\
\hline $\mathrm{R}_{S A}$ & $4.40 \mathrm{a}$ & $0.079 \mathrm{c}$ & 4.30 & $14.30 \mathrm{~b}$ \\
\hline RWW & $3.35 \mathrm{bc}$ & $0.075 \mathrm{~cd}$ & 5.87 & $15.87 \mathrm{a}$ \\
\hline RW & $3.21 \mathrm{bc}$ & $0.062 \mathrm{~d}$ & 5.47 & $15.47 \mathrm{a}$ \\
\hline CV (\%) & 36.57 & 29.44 & & 11.35
\end{tabular}

Means with equal letter in the same column are not statistically different ( $P \leq 0.05)$. Control: water at room conditions; $W W=$ wax + water at room conditions; RW $=$ Cold storage and placed in water; RSA = Cold storage and placed in salicylic acid solution; RWW = wax and cold storage and placed in water; RWSA = wax, cold storage and placed in salicylic acid. Where: $W L=$ weight loss; $S C=$ Solution consumption; $V L$ : vase life; $T V L=$ total vase life (including $10 \mathrm{~d}$ of storage)
The solution consumption is very low (0.15 $\left.\mathrm{mL} \mathrm{g}^{-1} \mathrm{PF}\right)$ compared to species such as rose (Rosa hybrida

L. cv. Black magic) with around 4
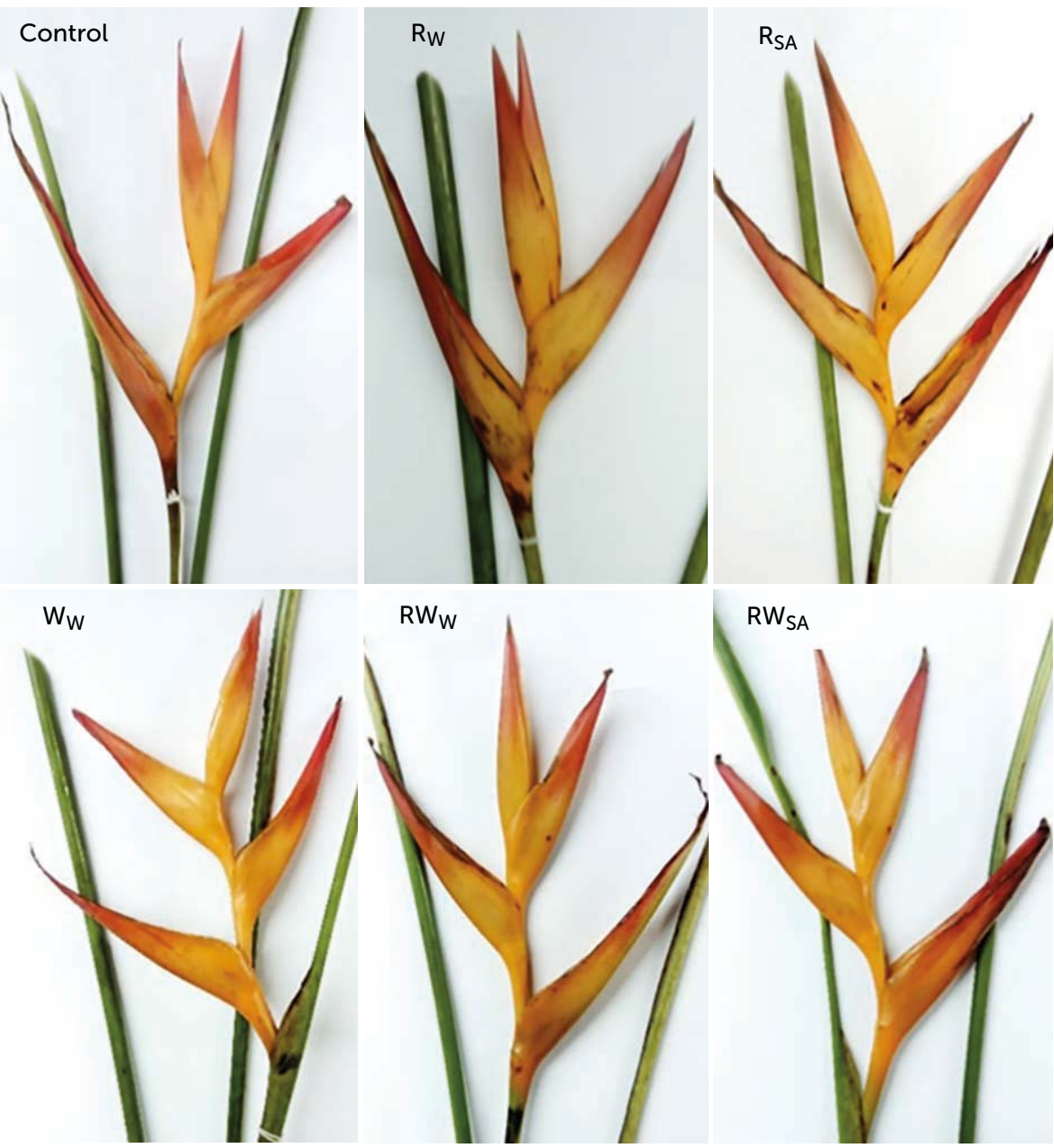

$\mathrm{RW}_{\mathrm{SA}}$

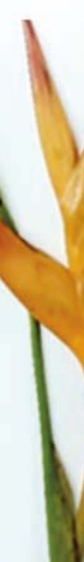

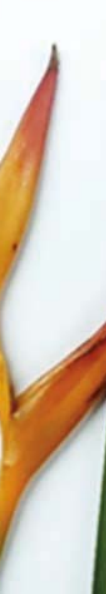

Figure 4. Heliconia psittacorum $\times$ H. spathocircinata $\mathrm{cv}$. Tropics five days after cold storage. Control: room temperature; $\mathrm{WW}=$ wax + water at room temperature; $\mathrm{RW}=$ Cold storage and placed in water; RSA = Cold storage and placed in salicylic acid solution; RWW = wax, cold storage and placed in water; RWSA = wax, cold storage and placed in salicylic acid.

$\mathrm{mL} \mathrm{g}^{-1}$ PF (Juárez et al., 2008) or lisianthus (Eustoma grandiflorum L.) with $0.55 \mathrm{~mL} \mathrm{~g}^{-1} \mathrm{PF}$ (Ahmad et al., 2012). This low absorption rate may be due to the size of the vascular bundles, because heliconia stems are thick and mostly made of spongy tissue; for this reason, the low response to the application of pulse or preservative solutions (Leyva-Ovalle et al., 2011). Similar results have been reported for other tropical species such as Alpinia purpurata "Red Ginger" (Ferreira et al., 2008) or Zingiber spectabile (Lessa et al., 2015) where the use of just water can maintain the quality and postharvest life of stems.

Given the low absorption capacity of heliconia, the only available technique to avoid the loss of water is the use of coatings, as reported in Anthurium andraeanum cut flowers (Mujaffar and Sankat, 2003) or in Heliconia bihai cv. Halloween (Bañuelos-Hernández et al., 2017) where the application of wax and chitosan, respectively, maintain the quality by limiting the weight loss. In this study, the waxing treatments maintained the heliconia stems quality by increasing the vase life. 


\section{CONCLUSIONS}

Stems of $H$. psittacorum $\times H$. spathocircinata $\mathrm{cv}$. Tropics maintain better quality if they store dry in cold temperatures, due the rotting reduction of the base stem and improves water absorption after storage. The use of pulse or preservative solutions does not improve postharvest quality due to the low absorption rate of heliconia stems (associated with their anatomical characteristics). The application of wax to the bracts proved to be the best option for preserving the turgor of flower stems, delaying senescence and reducing oxidation of the tissue.

\section{REFERENCES}

Abri, F., Ghasemnezhad, M., Hasansajedi, R. \& Bakhshi, D. (2013). Effect of Ascorbic Acid on Vase Life and Petal Senescence in Cut Rose Flowers (Rosa hybrida) cv. 'Royal Class.' Americaneurasian Journal of Agriculture and Environmental Sciences 13: 38-43. https://doi.org/10.5829/idosi.aejaes.2013.13.01.1901

Aghdam, M.S., Jannatizadeh, A., Sheikh-Assadi, M. \& Malekzadeh, P. (2016). Alleviation of postharvest chilling injury in anthurium cut flowers by salicylic acid treatment. Scientia Horticulturae 202: 70-76. https://doi.org/10.1016/j.scienta.2016.02.025

Ahmad, I., Dole, J.M., Amjad, A. \& Ahmad, S. (2012). Dry storage effects on postharvest performance of selected cut flowers. HortTechnology 22: 463-469. https://doi.org/10.21273/ HORTTECH.22.4.463

Albuquerque, A.W., Santos, J.M. \& Farias, A.P. (2014). Produtividade e qualidade póscolheita de Helicônia Golden Torch submetida a fontes e doses de silício. R. Bras. Eng. Agríc. Ambiental 18 (2): 173-179. doi:http://dx.doi.org/10.1590/S141543662014000200007

Arriechi, D. \& Sanabria, M.E. (1995). Ultraestructure of the epiderm of five species of Heliconia L. Revista del Decanato de Agronomía, UCLA 7: 63-69.

Bañuelos-Hernández, K.P., García-Nava, J.R., Leyva-Ovalle, O.R., Peña-Valdivia, C.B. \& Ybarra-Moncada, M.C. (2016). Flowering stem storage of Heliconia psittacorum L. f. cv. Trópica. Postharvest Biology and Technology 112: 159-169. https://doi. org/10.1016/j.postharvbio.2015.10.006.

Bañuelos-Hernández, K.P., García-Nava, J.R., Leyva-Ovalle, O.R., PeñaValdivia, C.B., Trejo \& Ybarra-Moncada, M.C. (2017). Chitosan coating effect on vase life of flowering stems of Heliconia bihai (L.) L. Cv. Halloween. Postharvest Biology and Technology 132 179-187. https://doi.org/10.1016/j.postharvbio.2017.05.009

Berlingieri-Durigan M. F., and B. H. Mattiuz. 2009. Effects of temperature on some senescence parameters during dry storage of cut flowers of gerbera "Suzanne". Acta Horticulturae 847: 399-407.

Castro, A.C.R., Willadino, L.G., Loges, V., Castro, M.F.A. \& Aragão, F.A.S. (2015). Macronutrients deficiency in Heliconia psittacorum × Heliconia spathocircinata "Golden Torch." Revista Ciência Agronômica 46 (2): 258-265. http://dx.doi.org/10.5935/18066690.20150005

Coelho, L.L., Carneiro, D.N.M., Paiva, P.D.O. \& Carneiro L.F. (2012). Soluções conservantes e pulsing na pós-colheita de Zingiber spectabile. Pesquisa Agropecuária Tropical 42: 482-485. ISNN:1983-4063

Elibox W. \& Umaharan, P. (2008). Morphophysiological characteristics associated with vase life of cut flowers of Anthurium. HortScience 43: 825-831. https://doi.org/10.17660/ ActaHortic.2014.1047.10

Ferreira, L.D.B., Evangelista, T.M., Pires, L.L., Castro, F.V. \& Silva, J.M. (2008). Durabilidade de inflorescências de Alpinia purpurata tratadas com solução de sacarose. Pesq. Agropec. Trop. 38:164-168 ISNN: 1517-6398

Folha, W.R., Souza, R.R., Amaral, G.C., Silva, A.A., Carvalho, J.N. \& Cavalcante, M.Z.B. (2016). Heliconia 'Golden Torch' postharvest: stem ends cutting and renewing vase water benefits. Ornamental Horticulture 22 (2): 180-185. https://doi. org/10.14295/oh.v22i2.908

Huang, X., Lin, S., He, S., Lin, X., Liu, J., Chen, R. \& Li, H. (2018). Characterization of stomata on floral organs and scapes of cut 'Real' gerberas and their involvement in postharvest water loss. Postharvest Biology and Technology 142: 39-45. https://doi. org/10.1016/j.postharvbio.2018.04.001

Juárez, P.H., Colinas L.M.T., Valdez, A.L.A., Espinosa, F.A., Castro, B.R. \& Cano, G.G.V. (2008). Soluciones y refrigeración para alargar la vida postcosecha de rosa cv. "Black Magic". Revista Fitotecnia Mexicana 31: 73-77. ISNN: 0187-7380

Lessa, M.A., Almeida, E.F.A., Nascimento, A.M.P., Curvelo, I.C.S., Reis, S.N., Nogueira D.A \& Paiva, P.D O. (2015). Postharvest conservation of ornamental ginger (Zingiber spectabile). Acta Horticulturae 1060: 307-313. https://doi.org/10.17660/ ActaHortic.2015.1060.46

Leyva-Ovalle, O.R., Rodríguez-Goya, A.Y., Herrera-Corredor, J.A., Galindo-Tovar, M.E. \& Murguía-González, J. (2011). Polímero hidrofílico combinado con soluciones preservadoras en la vida de florero de tallos florales de rosa y heliconia. Tropical and Subtropical Agroecosystems 13: 551-559 ISNN: 1870-0462

Mangave, B., Singh, A. \& Mahatma, M. (2013). Effects of different plant growth regulators and chemicals spray on post-harvest physiology and vase life of heliconia inflorescence cv. Golden Torch. Plant Growth Regulation 69: 259-264. https://doi. org/10.1007/s10725-012-9768-1

Moraes-Dias G. (2016). Quality maintenance Tropical Plants. Ornamental Horticulture 22: 256-258. https://doi. org/10.14295/oh.v22i3.961

Mosqueda-Lazcares G., Arévalo-Galarza, L., Valdovinos-Ponce, G. Rodríguez-Pérez, J. E. \& Colinas-León, M. T. (2012). Manejo y almacenamiento en seco y húmedo de cuatro cultivares de rosa de corte. Revista Chapingo Serie Horticultura 18(3): 317323.

Mujaffar, S. \& Sankat, C.K. (2003). Effect of waxing on the water balance and keeping qualities of cut anthuriums. Int. Agrophysics. 17: 77-84. ISNN: 0236-8722

Pun, U.K. \& Ichimura, K. (2003). Role of sugars in senescence and biosynthesis of ethylene in cut flowers. Japan Agricultural Research Quarterly 37 (4): 219-224. https://doi.org/10.6090/ jarq.37.219

van Doorn, W.G. (2012). Water Relations of Cut Flowers: An Update, in: Horticultural Reviews. Wiley-Blackwell, pp. 55-106. https://doi. org/10.1002/9781118351871.ch2 
van Meeteren, U. \& van Gelder, H. (1999). Effect of time since harvest and handling conditions on rehydration ability of cut chrysanthemum flowers. Postharvest Biology and Technology 16: 169-177. https://doi.org/10.1016/S0925-5214(99)00020-4 Villanueva-Couoh E., Alcántar-González, G., Sánchez-García, P., SoriaFregoso, M. \& Larque-Saavedra, A. (2009). Efecto del ácido salicílico y dimetilsulfóxido en la floración de [Chrysanthemum morifolium (Ramat) Kitamura] en Yucatán. Revista Chapingo. Serie Horticultura 15:25-31

Whistler, W. (2000). Tropical ornamentals: A guide. Inc. Portland Oregon, USA: Timber Press. $542 \mathrm{p}$

Woltering, E. J. \& Paillart, M.J.M. (2018). Effect of cold storage on stomatal functionality, water relations and flower performance in cut roses. Postharvest Biology and Technology 136: 66-73. https://doi.org/10.1016/j.postharvbio.2017.10.009

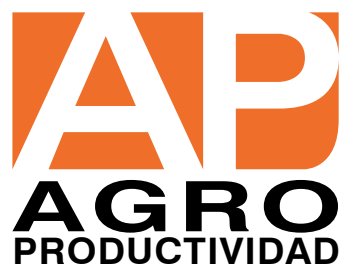

